\title{
The Consequences of Exchange Rate Fluctuations on Nigeria's Economic Performance: An Autoregressive Distributed Lag (ARDL) Approach
}

\author{
Nkemdilim Iheanachor ${ }^{1}$ \\ *Azuka Elvis Ozegbe ${ }^{2}$ \\ 'Lagos Business School, Ligigos, ligeriia \\ 2Iept. of Lconomicos, Lagoss State Iniversity, Lagos, ligeriia
}

\begin{abstract}
This study examined the effects of persistent exchange rate fluctuations on Nigeria's economic performance. It was motivated by the quest to ascertain why concerted efforts of the monetary authorities in Nigeria to pursue internal and external balances yielded little or no positive results in recent periods. The study employed the autoregressive distribution lag (ARDL) technique to test the short-run and long-run effects of exchange rate fluctuations on economic growth using annual time series data from 1986 to 2019. The empirical result revealed that the exchange rate, net direct foreign direct investments, and inflation rate had a significant adverse impact on Nigeria's economic growth in the long run. By implication, the net effect of this study established that excessive exchange rate fluctuations are detrimental to Nigeria's economic growth. On the premise of the empirical findings, this study recommends export diversification in agriculture and agro-investment in Nigeria. The state should influence the foreign exchange system through credible reforms that would reduce the adverse effects of an unstable foreign exchange system on the Nigerian economy.

Keywords: Exchange rate fluctuations, monetary policy, economic growth, Nigeria, Autoregressive Distribution Lag $(A R D L)$

JEL : C1, F4, F31
\end{abstract}

The Nigerian economy has been bedeviled by the challenge of instability in its foreign exchange rate market due to a high level of volatility (Kelikume and Nwani, 2019; Osabuohien et al., 2018). Exchange rate fluctuation is the continuous gyration in the foreign exchange market of nations which has emerged as the dominant subject of discussion in recent international finance literature owing to its fatal consequences on the economies of developing nations like Nigeria (Alagidede and Ibrahim, 2017; Barguellil et al., 2018; Senadza and Diaba, 2017).

In Nigeria, the formulation and implementation of the infamous Structural Adjustment Programme (SAP), a component of the Economic Recovery Program (ERP) in 1986, introduced financial sector reforms. Part of the reforms includes the jettisoning of the fixed exchange rates in favor of the freefloating regime in the late 1980s. This transition was conducted based on the assumption that flexible exchange rates would curb the boom-and-bust syndrome and turn the country towards a growth 
trajectory. The growth-enhancing impact emerging from the exchange rate channels are expected in the area of consumer price stability, volumes, investments and terms of trade. In Nigeria up to the time of the structural adjusted programme (SAP), it appeared that Nigerian's exchange rate policy deliberately encourages overvaluation of the Naira because, in 1981, it was $\$ 1$ to 0.90 cents. This, invariably, encouraged imports and discourages non-oil export and over-dependence of the Nigerian economy on imported input over exported output. An economy with its import exceeds export will experience an unfavorable balance of payment, and such economy's currency will be devalued against other country currencies involved in trades. The exchange rate of that country to other currencies will be low in terms of value; for example, the Nigerian Naira to dollars is $\$ 1$ to 197.00 , pounds-sterling is $£ 1$ to 281.29 etc. (Omoregie, 2020). The adverse impact of the global economic and financial crisis on the Nigerian exchange rate was a phenomenon as the Naira exchange rate to the dollar rose dramatically from about $120 / \$$ to more than $\$ 180 / \$$ between 2008 and 2009 . This is linked to the sharp drop in foreign earnings and national revenue of Nigeria due to the continuous fall of crude oil price in the world market. The renewed emphasis on the production of alternatives to fossil-fuel energy, such as wind, bio-energy and solar, in the advanced economies has made the demand for crude oil decline and consequently led to a sharp drop in the prices from $\$ 110$ per barrel to below $\$ 50$ per barrel between mid-2018 and early 2019 and currently at $\$ 38.77$ per barrel in the last quarter of 2020. This further weakened Nigeria's foreign earnings and revenues to finance priority sectors that will create jobs, boost economic activities, increase per capita income, and improve living standards.

Therefore, this study is motivated by the quest to investigate why the efforts of monetary authorities in Nigeria to vigorously pursue internal and external balances and improve standards of living for her citizenry. However, a desperate bid to achieve the above macro-economic goals and also ensure domestic price stability has yielded little or no positive results in recent periods. Given that the government has made several attempts to ensure exchange rate stability and sustainable economic growth since 1994, it is imperative to raise the following research questions to guide this inquiry. Why is there a persistent exchange rate fluctuation in Nigeria? What are the effects of exchange rate fluctuation on Nigeria's economic performance? Answering these questions will provide essential insights to the various economic agents such as policymakers, public and private investors, and the nexus between exchange rate and economic performance in Nigeria.

Concerns about the consequences of exchange rate fluctuations in both developed and developing economies like Nigeria have evolved in an astonishing manner owing to its impact on exports (Abdoh et al., 2016; Caselli et al., 2017; Fauceglia, 2020; Vieira and MacDonald, 2016; Vo and Zhang, 2019), employment growth (Bakhshi and Ebrahimi, 2016; Fang, 2020; Usman and Elsalih, 2018), trade (Asteriou et al., 2016; Jadoon and Guang, 2019; Rashid and Waqar, 2017; Senadza and 


\section{Iheanachor \& Ozegbe}

Diaba, 2017), inflation (Alagidede and Ibrahim, 2017; Bagheri and Gheisarinejad, 2016), investment (Avdjiev et al., 2019; Mostafapour et al., 2020; Zakari, 2017), and more general economic activity (Adewuyi and Akpokodje, 2013; Akinlo and Onatunji, 2020), and growth (Alagidede and Ibrahim, 2017; Habib et al., 2017; Isola et al., 2016; Vasani et al., 2019).

While anecdotally, the exchange rate volatility has been linked to macroeconomic instability, a minimal attempt has been made to investigate the factors behind it and its impact on internal and external stability. Moreover, discussions surrounding Nigeria's exchange rate fluctuations are only gleaned from public discourses on the economy with very little empirical and theoretical content. As such, to bridge the theoretical and empirical gaps and improve on the weaknesses of the previous studies from the Nigerian context, this study built its theoretical foundation on the optimal currency area (OCA) theory, propounded by Mundell (1961), and McKinnon (1963).

Therefore, the purpose of this inquiry is to ascertain the effects of exchange rate fluctuations on the performance of the Nigerian economy by employing the autoregressive distribution lag (ADRL) method to empirically test the framework built on the optimal currency area (OCA) theory. The theory is based on concepts of the symmetry of shocks, the degree of openness, and labor market mobility. It assumes that a fixed exchange rate regime can increase trade and output growth by reducing exchange rate uncertainty and the cost of hedging and encouraging investment by lowering currency premium from interest rates. However, it can also minimize trade and output growth by stopping, delaying or slowing the necessary relative price adjustment process.

The rest of this paper is structured as follows: Section two comprises the literature review; section three focuses on the methodology; section four presents the results, while section five concludes the paper by outlining the summary of findings, policy implications, and limitations and future directions.

\section{LITERATURE REVIEW}

\section{An Overview of Nigeria's Foreign Exchange Policies}

The Nigerian exchange rate policies and regimes have undergone a plethora of changes in the last six decades. It had evolved from a fixed parity in 1960 when it was tied with the British Pound Sterling. Sequel to the devaluation of the Pound Sterling in 1967, the US dollar was introduced in the parity exchange arrangement. The parity exchange rate policy with the British Pound was suspended in 1972 due to the emergence of the stronger US Dollar. The fixed parity with the British Pound was reintroduced in 1973 due to the weakening of the US Dollar. To mitigate the adverse impact of the devaluation, the Nigerian currency was tied to the US Dollar and Pounds in 1974. Almost throughout the 1970s, there was a persistent appreciation of the nominal exchange rate of the Naira occasioned 
by increases in crude oil price in the global market. These appreciations in the nominal exchange rates led to over-dependence on imports coupled with discouraging non-oil exports and capital flight which ultimately led to external reserve depletion and balance of payments problems. Nigeria's agricultural sector collapsed due to a rising marginal propensity to import (Eze and Okpala, 2014). The Naira was tied to a basket of 12 currencies which included critical trading partners in 1978. Nevertheless, the 1978 policy was jettisoned in 1985 in favor of quoting the Naira against the dollar. Before 1986, the general exchange rate policies encouraged the over-valuation of the Naira (Eregha et al., 2016).

The Naira was deregulated in September 1986 under the Structural Adjustment Programme Package to address the issues associated with the over-valuation. The Second-tier Foreign Exchange Market (SFEM) was introduced to boost the Structural Adjustment Programme. The mandate of SFEM was to design a mechanism for exchange rates determination and allocation to ensure short-term stability and long-term balance of payments equilibrium. As stated by Godfrey and Agwu (2019), the essential objectives of SFEM include achieving a realistic Naira exchange rate through the interplay of the forces of demand and supply. Stimulation of non-oil exports, ensuring efficient allocation of resources, eliminating currency trafficking by wiping out unofficial parallel foreign exchange market, encouraging foreign exchange inflow and discouraging outflow, and ensuring the balance of payments situation of the country. Several modifications were made to attain the goals of SFEM, ranging from Foreign Exchange Market (FEM) to Autonomous Foreign Exchange Market (AFEM), to Dutch Action System and, to the wholesale Dutch Auction System. The FEM was introduced due to the problem arising from the first and second-tier market rates in July 1987. In 1989 the Bureau de change was introduced to broaden the scope of FEM. The foreign exchange rate system was reintroduced in 1994. In 1995, a policy reversal of guided deregulation was referred to as the Autonomous Foreign Exchange Market (AFEM). The interbank foreign exchange market (IFEM was reintroduced in 1999. This brought about the merger of the dual exchange rate, following the abolition of the official exchange rate from January 1, 1999. In 2002, the Dutch Auction System (DAS) was reintroduced due to the rising demand pressure in the foreign exchange market and the continuous depletion of the country's external reserves. Finally, the introduction of wholesale DAS in 2006 further liberalized the market to evolve a realistic exchange rate of the Naira. Until now, Nigeria's exchange rate regime is characterized as oscillating between fully-managed and freely floating regimes. From 2016 the regulatory authority CBN reintroduced the managed floating FOREX system titled "Flexible Exchange Rate Inter-bank Market" (Eregha et al., 2016). Table 1 (see Appendix-I) presents the scheme of events in exchange rate management in Nigeria.

\section{Administration of Exchange Rate Policy and Capital Control in Nigeria}




\section{Iheanachor \& Ozegbe}

A review of existing literature and data reveals that political factors have influenced Nigeria's economic policies, including exchange rate and capital control measures (Akinlo and Onatunji, 2020). The policymakers respond to political pressures and roll out policies that reflect the choices of their political paymasters rather than economic realities. Hence, some of the exchange rate policies and capital control measures introduced by the apex bank in Nigeria since independence are the outcome of political preferences or expediencies. Indeed, the different and sometimes conflicting exchange rate policies and policy regimes in the country are mainly due to the time's political realities, which explain the high rate of instability and inconsistency in foreign exchange policies by different government regimes in the country.

From the above facts, exchange rate policies are likely to be affected by varieties of political factors, including election timing. The real exchange rate affects broad economic aggregates like the purchasing power, the cost of export, the price level and the real wage, which are all relevant to elections as some voters use them as indices for selecting their leader. Indeed, governments tend to appreciate currencies before elections, delaying a depreciation/devaluation until after the election (Kaltenbrunner and Painceira, 2017). Given the political unpopularity of a devaluation-induced reduction in national purchasing power, governments may refuse to devalue the currency, not because of any economic reason but purely on political consideration.

Exchange rate policies and capital control measures in Nigeria have also been influenced by the nature and character of the political leadership. Regimes/administrations that are pro-west tend to key into the global trend towards greater economic liberalization as recommended by the World Bank and the IMF. These regimes pursue floating or market-based exchange rate system. Two regimes that stand out in this regard are those of General Ibrahim Babangida (1985 to 1993) and Chief Olusegun Obasanjo (1999 to 2007). On the other hand, administrations that are not necessarily anti-west but do not subscribe to the global trend towards economic liberalization tend to pursue a fixed exchange rate system. An example is the government of General Sani Abacha (1994 to 1998).

\section{Theoretical Foundation}

\section{-The Optimal Currency Area (OCA) Theory}

The ground-breaking optimal currency area (OCA) theory, developed by Mundell (1961) and McKinnon (1963), remains a theoretical foundation for the adoption of exchange rate policies. This theory emphasizes the need to ensure stability in the business cycle and trade. It is based on concepts of labor market mobility, degree of openness, and symmetry of shocks. In the view of the theory, a fixed exchange rate regime can accelerate trade and output growth by reducing exchange rate uncertainty 
and the cost of hedging and encouraging investment by reducing currency premium from interest rates. Nevertheless, it can also retard output growth and trade by slowing down and stopping the necessary relative price adjustment process.

Contemporary exchange rate theories are anchored on the monetary and the asset market or portfolio balance approaches to the balance of payments and view the exchange rate, for the most part, as a purely financial phenomenon. On the other hand, a traditional exchange rate theory lays emphasis on trade flows and contributes to the explanation of exchange rate gyration in the long run. With financial flows now dwarfing trade flow, interest has shifted to modern exchange rate theories, but traditional theories remain essential in the long run (Salvatore, 2012).

\section{-Exchange Rate Volatility and Economic Growth}

Following the seminal work of Mundell (1961) and McKinnon (1963) on optimum currency area (OCA) theory, examining exchange rates and how they contribute to the economic growth and overall performance in the short, medium and long-term has been a topical subject of debate in the international trade and finance literature. However, there is an absence of consensus among scholars in this research space. Even though some studies (Greenaway-McGrevy, 2018; Ismailov and Rossi, 2018) find evidence that exchange rates co-move with macroeconomic fundamentals over long horizons, contemporary literature in international finance is: exchange rates are unpredictable, especially at short horizons (Della et al., 2009). Bristy (2014) applied the optimum currency area (OCA) theory in ascertaining how exchange rate volatility and financial development affect the longterm growth of Bangladesh. The empirical result revealed that exchange rate volatility adversely hurts the growth of the Bangladeshi economy. Similarly, Alagidede and Ibrahim (2017) assessed the causes and effects of exchange rate volatility on Ghana's economic performance using the vector error correction model (VECM) to analyze the annual time-series data spanning 1980 to 2013. The study revealed that excessive volatility adversely affects Ghana's economic growth. However, this is only up to a point as the growth-enhancing effect can also emanate from innovation and efficient resource allocation. Libman (2018) argued that maintaining an appropriate and stable exchange rate enables various economies to explore their growth and development capacities. Excess exchange rate volatility has been identified to reduce economic growth by creating business uncertainty, deteriorating competitiveness, lowering productivity and profits, and increasing domestic prices. Ahiabor and Amoah (2019) examined the link between exchange rate volatility and long-run productivity growth. It revealed a non-linearity between real exchange rate volatility and output volatility among emerging market economies. Their finding suggests that real exchange rate volatility aids in absorbing shock and limiting output volatility, but too much volatility in the exchange rate increases output volatility. 


\section{Iheanachor \& Ozegbe}

Adelowokan et al. (2015) evaluated the effect of exchange rate volatility on investment and growth in Nigeria using the vector error correction (VEC) method and found out that exchange rate volatility has a negative effect on investment and growth while exchange rate volatility has a positive relationship with inflation and interest rate in Nigeria. Rapetti et al. (2012) presented evidence that real exchange rate volatility impedes economic growth and reduces productivity and growth in a large sample of industrial and developing countries. Oseni (2016) also analyzed the effect of exchange rate volatility and private sector consumption in Sub-Sahara Africa. The study employed generalized method of moments (GGM) dynamic panel regression econometric tools, which showed a negative relationship between exchange rate volatility and manufacturing sector performance.

However, some previous studies have also revealed that the exchange rate has a significant positive effect on economic growth performance. For instance, Vieira et al. (2016) examined the impact of real exchange rate volatility on long-run economic growth for advanced and emerging economies over the period 1970 to 2009 and found that high (low) exchange rate volatility positively (negatively) affects real gross domestic product (GDP) growth rate. However, controlling for exchange rate volatility in a model containing levels of exchange rate and exchange rate misalignment renders the variables insignificant, suggesting that exchange rate stability is more crucial in propelling long-run growth than exchange rate misalignment. Aliyu (2011) affirmed that appreciation of the exchange rate increases imports and reduces exports, while depreciation would expand export and discourage import. Also, depreciation of the exchange rate is likely to cause a shift from foreign goods to domestic goods. Thus, it leads to the diversion of income from importing countries to countries exporting through a shift in terms of trade, which tends to impact exporting and importing countries' economic growth.

The empirical and theoretical review above revealed inconclusiveness in the results of extant studies. The emphasis placed on the exchange rate and economic growth nexus as shown in the literature and the inconsistency of successive Nigerian political administrations in implementing exchange policies forms the basis for the investigation. Therefore, to address the empirical and theoretical gaps identified in the literature, the hypothesis stated below will be tested.

$H_{0}$ : Exchange rate fluctuations do not affect Nigeria's economic growth.

\section{METHODOLOGY}

\section{-Sample and Data}

This study employed annual time series data spanning 33 years between 1986 and 2019 for the empirical analysis. The independent variables for this study include the exchange rate proxied by the 
official local currency (Naira)/ US Dollar exchange rate. Exchange rate data are available at different frequencies. However, this study depended on the annual time series data, given that other macroeconomic variables are only available on an annual basis. Therefore, annulling the possibility of utilizing daily, monthly or quarterly data, this possesses larger samples. The foreign direct investment (FDI) was proxied by foreign direct investment net inflows as a percentage of GDP. Inflation was proxied by inflation rate while interest rate was proxied by real interest rate. The dependent variable gross domestic product (GDP), which represented economic performance in this study, was proxied by the annual growth rate of the real GDP. The data on GDP and exchange rate were extracted from the Central Bank of Nigeria (CBN) statistical bulletin for the real and external sectors, respectively. The data on foreign direct investment, inflation and interest rate were obtained from the World Development Indicator (WDI) of the World Bank.

\section{-Data Analysis Techniques}

The empirical analysis in this study includes the preliminary analysis, estimation and post estimation. The preliminary analysis includes descriptive statistics, unit-roots test, and co-integration test. Regarding the co-integration test (bounds co-integration test) and estimation, the study employed Autoregressive Distribution Lag (ADRL) to examine the short-run and long-run relationships. There is evidence of a long-run relationship if the computed $f$-statistics exceeds the upper bound critical value. However, there is no co-integration if the $f$-statistic is below the lower bound, while the result will be considered inconclusive for a value within lower and upper bounds. The pre-estimation tests, which include normality test, heteroscedasticity test, and serial correlation test, were conducted to examine the adequacy and reliability of the specified model.

\section{-Model Specification}

Based on the optimal currency area (OCA) theory of exchange rate espoused by Mundell (1961) and McKinnon (1963), and the empirical studies of Vieira and MacDonald (2016) and Babajide et al. (2016). The study adopted the model developed by Adeniran et al. (2014) and employed the growth rate of real GDP as a proxy for economic growth. In addition to Naira/Dollar exchange rate, other independent variables employed are net foreign direct investment, inflation rate, and interest rate.

The functional form of the model is specified as follows:

$$
G G D P_{t}=f\left(E X R_{t}, N F D I_{t}, I N F_{t}, I N T_{t}\right)
$$

Where $G G D P=$ Growth rate of GDP, EXR $=$ Naira/Dollar exchange rate, $N F D I=$ Net foreign direct inves- 


\section{Iheanachor \& Ozegbe}

tment, $I N F=$ Inflation rate, and $I N T=$ Interest rate.

Hence, the specific ARDL model for this study is expressed as follows:

$$
G G D P_{\mathrm{t}}=\theta+\sum_{\mathrm{i}=1}^{p} \alpha_{\mathrm{i}} G G D P_{\mathrm{t}-\mathrm{i}}+\sum_{\mathrm{i}=0}^{q_{1}} \beta_{1 \mathrm{i}} \log \left(E X R_{\mathrm{t}-\mathrm{i}}\right)+\sum_{\mathrm{i}=0}^{q_{\mathrm{z}}} \beta_{2 \mathrm{i}} N F D I_{\mathrm{t}-\mathrm{i}}+\sum_{\mathrm{i}=0}^{q_{\mathrm{i}}} \beta_{\mathrm{ii}} I N F_{\mathrm{t}-\mathrm{i}}+\sum_{\mathrm{i}=0}^{q_{\mathrm{t}}} \beta_{4 \mathrm{i}} I N T_{\mathrm{t}-\mathrm{i}}+\varepsilon_{\mathrm{t}}
$$

Where $p, q_{1}, q_{2}, q_{3}$ and $q_{4}$, are the respective maximum lags of the dependent variable (GGDP) and the explanatory variables (EXR, NFDI, INF, INT) while $\alpha_{i}, \beta_{1 i}, \beta_{2 i}, \beta_{3 i}$, and $\beta_{4 i}$ are the respective coefficients associated with the dependent variable (GGDP) and the explanatory variables at the respective lags.

The ARDL Error Correction Model (ECM) specification is given as:

$$
\begin{gathered}
\Delta G G D P_{\mathrm{t}}=\theta+\sum_{\mathrm{i}=1}^{p} \alpha_{\mathrm{i}} \Delta G G D P_{\mathrm{t}-\mathrm{i}}+\sum_{\mathrm{i}=1}^{q_{1}} \beta_{1 \mathrm{i}} \Delta E X R_{\mathrm{t}-\mathrm{i}}+\sum_{\mathrm{i}=1}^{q_{2}} \beta_{2 \mathrm{i}} \Delta N F D I_{\mathrm{t}-\mathrm{i}}+\sum_{\mathrm{i}=1}^{q_{3}} \beta_{\mathrm{ai}} \Delta I N F_{\mathrm{t}-\mathrm{i}}+\sum_{\mathrm{i}=1}^{q_{4}} \beta_{4 \mathrm{i}} \Delta I N T_{\mathrm{t}-\mathrm{i}} \\
+\emptyset E C M_{\mathrm{t}-\mathrm{i}}+\epsilon_{\mathrm{t}}
\end{gathered}
$$

In equation (3.3), the coefficient ( $\emptyset)$ of the ECM term called the speed of adjustment is expected to be negative in order to restore the model to equilibrium, i.e., $\emptyset<0$.

Given equation (3.4), the long run form of the ARDL is specified as follows:

$$
\begin{aligned}
& \qquad G G D P_{t}=\psi_{0}+\psi_{1} E X R_{t}+\psi_{2} N F D I_{t}+\psi_{3} I N F_{t}+\psi_{4} I N T_{t} \\
& \text { Where } \psi_{1}<1, \psi_{2}>0, \psi_{3}><0, \psi_{4}<0
\end{aligned}
$$

\section{Analysis and Results}

This section presents the results of the empirical analysis involving descriptive analysis, unit root test analysis, co-integration test, and the post estimation test.

\section{-Descriptive Statistics}

The descriptive statistics for all variables are shown in Table 2. The Jarque-Bera statistics for the sampled period 1986 - 2019 indicate that growth rate of real GDP (GGDP) and Naira/Dollar exchange (EXR) are normally distributed since their $p$-values ( 0.4708 and 0.2684 , respectively) are greater than 5 percent level of significance. On the contrary, net foreign direct investment (NFDI), inflation rate (INF) and interest rate (INT) do not follow a normal distribution since their $p$-values $(0.0462,0.0001$ and 0.0017 , respectively) of the Jarque-Bera statistics are less than 0.05 . 


\section{-Heteroscedasticity Test}

Table 3 (see Appendix-II) presents result for heteroscedasticity test. Since the $p$-values of both the $f$ statistic and observed R-squared are greater than 0.05 , the null hypothesis (i.e., absence of heteroscedasticity) is accepted. Thus, the model estimated does not suffer from heteroscedasticity for the considered sample period.

\begin{tabular}{cccccc}
\hline & $\boldsymbol{G G D P}$ & $\boldsymbol{E X R}$ & $\boldsymbol{N F D I}$ & $\boldsymbol{I N F}$ & $\boldsymbol{I N T}$ \\
\hline Mean & 4.770882 & 108.0132 & -2.458824 & 19.69853 & 18.88382 \\
Median & 4.760000 & 119.7700 & -1.835000 & 12.38500 & 17.87500 \\
Maximum & 14.60000 & 306.9200 & -0.190000 & 72.84000 & 31.65000 \\
Minimum & -1.580000 & 2.020000 & -8.020000 & 5.390000 & 9.960000 \\
Std. Dev. & 3.786089 & 91.70723 & 2.230290 & 18.06083 & 3.885104 \\
Skewness & 0.502520 & 0.669119 & -1.041176 & 1.658268 & 0.966191 \\
Kurtosis & 2.769018 & 2.743564 & 2.925799 & 4.381147 & 5.299730 \\
\hline Jarque-Bera & 1.506564 & 2.630238 & 6.150736 & 18.28489 & 12.78238 \\
Probability & 0.470819 & 0.268442 & 0.046173 & 0.000107 & 0.001676 \\
\hline Sum & 162.2100 & 3672.450 & -83.60000 & 669.7500 & 642.0500 \\
Sum Sq. Dev. & 473.0375 & 277537.1 & 164.1484 & 10764.39 & 498.1030 \\
\hline Observations & 34 & 34 & 34 & 34 & 34 \\
\hline
\end{tabular}

Source: Authors' Computation using EViews

Table 2. Descriptive Statistics (1986 - 2019)

\section{-Autocorrelation}

Table 4 (see Appendix-II) presents the result of the serial correlation test. Since the $p$-values of both the $f$-statistic and observed $\mathrm{R}$-squared are greater than 5 percent level of significance, the null hypothesis (i.e., no serial correlation) is therefore accepted. Thus, the model estimated does not suffer from serial correlation for the given sample period.

\section{Unit Root Tests}

The unit root tests were conducted prior to the estimation of ARDL model. Thus, the Augmented Dickey-Fuller (ADF) test of unit root was conducted for each variable and the results of the unit root tests are presented in the Table 5. The table shows that the series viz. growth of GDP (GGDP), inflation rate $(I N F)$ and interest rate $(I N T)$ are stationary at level, i.e., they are $I(0)$ series while exchange rate $(E X R)$ and net foreign direct investment (NFDI) are integrated at order one, i.e., they are $I(1)$ series. Thus, the combinations of $I(0)$ and $I(1)$ orders of integration of the variables justify the use of the bound co-integration test to examine the existence of a long-run relationship between the dependent variable and the regressors as proposed by Pesaran et al. (2001).

\section{ARDL Bounds Test for Co-integration}




\section{Iheanachor \& Ozegbe}

\begin{tabular}{|c|c|c|c|c|c|c|}
\hline Variable & Test order & $\begin{array}{c}\text { ADF- } \\
\text { Statistics }\end{array}$ & $\begin{array}{c}\text { Critical } \\
\text { Value }\end{array}$ & $\begin{array}{c}\text { Level of } \\
\text { Significance }\end{array}$ & $p$-value & $\begin{array}{c}\text { Order of } \\
\text { integration }\end{array}$ \\
\hline$G G D P$ & Level & -3.0449 & -2.9540 & $5 \%$ & 0.0410 & $I(0)$ \\
\hline \multirow{2}{*}{$E X R$} & Level & -2.6499 & -2.9540 & $5 \%$ & 0.0936 & \multirow{2}{*}{$I(1)$} \\
\hline & $1^{\text {st }}$ Difference & -5.7116 & -2.9571 & $5 \%$ & 0.0000 & \\
\hline \multirow{2}{*}{ NFDI } & Level & -1.8192 & -2.9540 & $5 \%$ & 0.3650 & \multirow{2}{*}{$I(1)$} \\
\hline & $1^{\text {st }}$ Difference & -7.2374 & -2.9571 & $5 \%$ & 0.0000 & \\
\hline INF & Level & -4.3559 & -2.9810 & $5 \%$ & 0.0022 & $I(0)$ \\
\hline INT & Level & -3.2767 & -2.9540 & $5 \%$ & 0.0243 & $I(0)$ \\
\hline
\end{tabular}

Source: Authors' Computation using EViews

Table 5. Unit Root Tests Results (1986 - 2019)

Table 6 presents the results of the bounds co-integration test using ARDL. Thus, since the $f$-statistic (4.6755) exceeds the upper bounds of the critical value bounds at the various levels of significance, there is evidence of a long-run relationship among the variables. That is, the growth rate of real GDP $(G G D P)$, Naira/Dollar exchange rate (EXR), net foreign direct investment (NFDI), inflation rate (INF) and interest rate (INT) are co-integrated.

\begin{tabular}{ccrrr}
\hline Test Statistic & Value & Sig. & $\mathbf{I}(\mathbf{0})$ & $\mathbf{I}(\mathbf{1})$ \\
\hline$f$-statistic & 4.675543 & $10 \%$ & 1.9 & 3.01 \\
$\mathrm{~K}$ & 4 & $5 \%$ & 2.26 & 3.48 \\
& & $2.5 \%$ & 2.62 & 3.9 \\
& & $1 \%$ & 3.07 & 4.44 \\
\hline
\end{tabular}

Source: Authors' Computation using EViews

Table 6. Result Bounds Test for Cointegration

\section{Model Estimation}

\section{-Estimation of ARDL Short-Run Coefficients}

Table 7 (see Appendix-III) presents the result of the short-run form (error correction model) of the ARDL. The coefficient $(-0.9282)$ of the ECM (error correction term or speed of adjustment) is negative and significant (since the p-value of 0.0001 is less than 5\%). This suggests that GGDP adjusts to EXR, NFDI, INF and INT in the long-run. Thus, about 92.82 percent of the disequilibrium in the previous periods has fallen back to equilibrium in the current period. Therefore, the model has restored to equilibrium.

\section{-Estimation of ARDL Long-Run Coefficients}

Table 8 (see Appendix-IV) presents the result of the estimated long-run form of the ARDL for the given sample period. The estimated long-run equation shows that exchange rate $(E X R)$, net foreign direct 
investment (NFDI), and inflation rate (INF) at 5 percent level of significance have significant negative impacts on the growth rate of GDP (GGDP) in Nigeria, having $p$-values of $0.0137,0.0379$, and 0.0011 , respectively. In contrast, interest rate (INT) significantly impacts GGDP (a proxy for Nigerian economic growth), having a $p$-value of 0.0003 . Therefore, one percent fall (rise) in each of EXR and INF will lead to a rise (fall) in GGDP by about 0.016 percent and 0.307 percent, respectively, while every one billion US Dollar decrease (increase) in NFDI will result in about 0.589 percent increase (decrease) in GGDP. However, every one percent rise INT will, on average, result in about a 0.88 percent rise in GGDP. Thus, the exchange rate (EXR), net foreign direct investment (NFDI), and inflation rate (INF) have significant negative long-run impacts on economic growth in Nigeria, while interest rate (INT) has a significant positive long-run impact on economic growth. More importantly, Naira/Dollar exchange rate fluctuations exert a negative impact on Nigerian economic growth. A rise in the value of Naira relative to the Dollar will enhance the growth of the Nigerian economy and vice versa.

\section{-Stability Test (CUSUM test)}

Figure 1 presents the result of the test of stability using CUSUM criterion. Since the plot remains within the critical bounds at 5 percent level of significant, thus, the model is structurally stable. Therefore, the estimated ARDL parameters are stable and appropriate for long-run decision making.

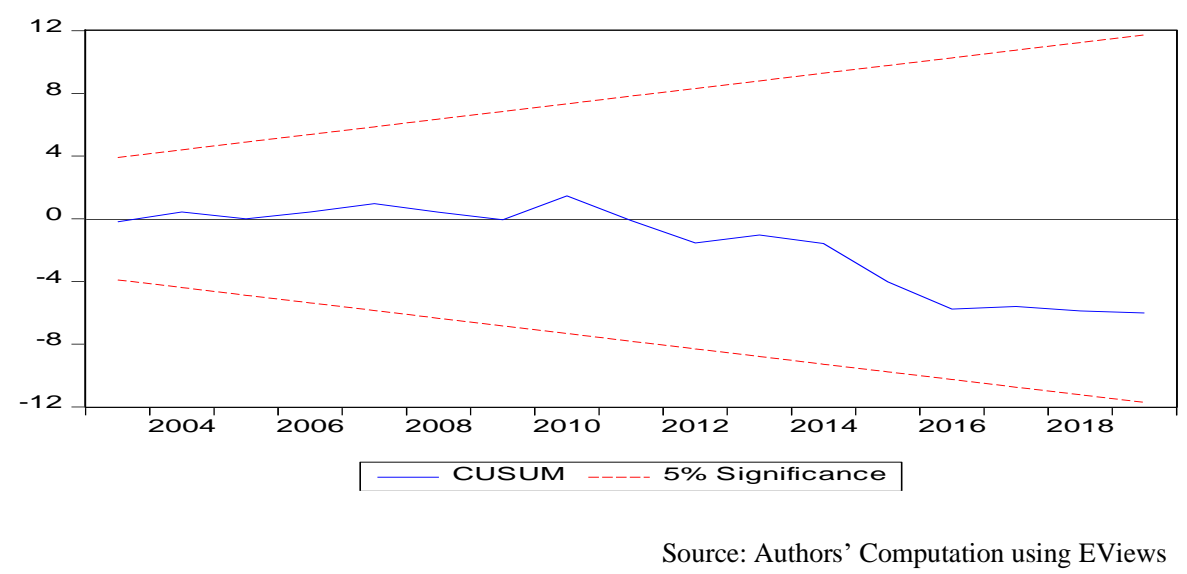

Figure 1. Plot of Cumulative Sum (CUSUM) of Recursive Residuals

\section{DISCUSSION}

The seminal work of Mundell (1961) and Mckinno (1963) emphasized the usefulness of exchange rate policies in adjusting relative pricing among economies. It argued that fixed exchange rate regimes have the propensity to raise the level of trade and output growth by reducing uncertainty and thus the cost of hedging and encouraging investment by lowering currency premium from interest rates. 


\section{Iheanachor \& Ozegbe}

Contrary to the optimal currency area (OCA) theory, present study revealed that the exchange rate, net foreign direct investment and inflation rate had a significant adverse impact on the growth of the Nigerian economy within the period under review. This implies that a rise in the value of the Naira relative to the US Dollar will accelerate Nigeria's economic growth and vice-versa. This outcome is consistent with the findings of Alagiedede and Ibrahim (2017) that examined the causes and effects of exchange rate volatility on Ghana's economic growth and revealed that excessive volatility negatively affected the Ghanaian economy. The findings of present study also corroborate the empirical revelation of Greenaway-McGrevy et al. (2018), who argued that maintaining appropriate and stable exchange rates enables various economies to explore their growth and development capacities. The study further revealed that excessive exchange rate fluctuations impeded economic growth by creating uncertainty in business, deteriorating competitiveness, reducing productivity and profit. On the contrary, empirical studies (e.g., Akpan, 2008; Azeez et al., 2012; Isibor et al., 2018; Vieira and MacDonald, 2016) revealed that exchange rate fluctuations have positive long-term effects on economic growth. High (low) exchange rate fluctuations positively (negatively) affect the real GDP growth rate (Vieira and MacDonald, 2016).

\section{CONCLUSION}

This study used the theoretical framework of optimal currency area (OCA) to examine the nexus between exchange rate fluctuations and Nigeria's economic growth by relying on annual time series data spanning 1986 to 2019. Applying the auto-regressive distributed lag (ARDL) technique, the results revealed that in the long-run exchange rate (EXR), net foreign direct investment (NFDI), and inflation rate (INF) has a significant negative impact on the growth rate of GDP in Nigeria. In contrast, interest rate (INT) has a positive significant long-run impact on economic growth. Stating succinctly, Naira/US Dollar exchange rate fluctuations negatively impact Nigeria's economic growth. A rise in the value of Naira relative to the US Dollar will enhance Nigeria's economic growth and vice-versa. The net effect of our study establishes that excessive volatility is detrimental to growth.

Nevertheless, is this always the case? If indeed the answer was in the affirmative, the consequences could be significant. The result implies that in the short-run, when economic growth is the target of policymakers, manipulating the exchange rate regime will induce an increase in RGDP though this relationship dissolves in the long-run.

\section{IMPLICATIONS}


Following the postulation of optimal currency area (OCA) theory Mundell (1961) and McKinnon (1963) advocates fixed and stable exchange rate regime to accelerate trade, increase output growth by lowering uncertainties, cost of hedging and encouraging investments by reducing premium exchange rates. This study revealed that the exchange rate, net direct foreign investment and inflation rate has an adverse effect on Nigeria's economic growth, while interest rate has a positive long-run effect on the nation's economic growth. The implication of the result is that in the short run, when economic growth is the target of policymakers, manipulating the exchange rate regime will induce an increase in RGDP though this relationship dissolves in the long-run.

On a practical purview, the state plays a critical role in stabilizing the economy, and as such, the state should stimulate export diversification in the area of agriculture and agro-investments. Agroallied industries and oil allied industries will improve foreign exchange earnings on real growth in the Nigerian economy. Finally, the government should influence the foreign exchange rate by positive economic reforms that will reduce the adverse effects of unstable foreign exchange rate on the Nigerian economy concerning trade flow.

\section{LIMITATIONS AND FUTURE DIRECTIONS}

This inquiry focused on assessing the impact of exchange rate fluctuations on the performance of the Nigerian economy measured by gross domestic product growth rate using the optimal currency area (OCA) theory. Nevertheless, the study has some weaknesses and limitations, which could present a fertile soil for the cultivation of future research ideas. The outcome of this study is based on a countryspecific analysis that focused on Nigeria, which implies that the result may not be valid in the context of generalization. However, the findings may likely be the case for many frontiers and emerging economies other than Nigeria. As such, future inquiries may focus on examining the connections among exchange rate, trade-openness and economic performance of frontier and emerging economies by engaging in a cross-country assessment of these connections to guarantee the generalization of their results.

\section{REFERENCES}

Abdoh, W. M. Y. M., Yusuf, N. H. M., Zulkifli, S. A. M., Bulot, N., \& Ibrahim, N. J. (2016). Macroeconomic factors that influence exchange rate fluctuation in ASEAN countries. International Academic Research Journal of Social Science, 2(1): 89-94.

Adelowokan, O. A., Adesoye, A. B., \& Balogun, O. D. (2015). Exchange rate fluctuation on investment and growth in Nigeria, an empirical analysis. Global Journal of Management and Business Research: B Economics and Commerce, 15(10): 567582.

Adeniran, J. O., Yusuf, S. A., \& Adeyemi, O. A. (2014). The impact of exchange rate fluctuation on the Nigerian economic growth: An empirical investigation. International Journal of Academic Research in Business and Social Sciences, 4(8): 224233. https://doi.org/10.6007/IJARBSS/v4-i8/1091

Adewuyi, A. O., \& Akpokodje, G. (2013). Exchange rate volatility and economic activities of Africa's sub-groups. The International Trade Journal, 27(4): 349-384. https://doi.org/10.1080/08853908.2013.813352 


\section{Iheanachor \& Ozegbe}

Ahiabor, G., \& Amoah, A. (2019). Examining the effect of real effective exchange rate volatility on economic growth: Evidence from Ghana. Journal of Economics and Economic Education Research, 20(1): 1-14.

Akpan, P. L. (2008). Unemployment and exchange rate uncertainty in an emerging Sub-Saharan economy: A case for Nigeria (1970-2005). Global Journal of Social Sciences, 7(2): 226-241. https://doi.org/10.4314/gjss.v7i2.48850

Akinlo, A. E., \& Onatunji, O. G. (2020). Exchange rate volatility and domestic investment: Evidence from twelve ECOWAS countries. African Journal of Economic Review, 8(2):176-189. https://doi.org/10.22004/ag.econ.304721

Alagidede, P., \& Ibrahim, M. (2017). On the causes and effects of exchange rate volatility on economic growth: Evidence from Ghana. Journal of African Business, 18(2): 169-193. https://doi.org/10.1080/15228916.2017.1247330

Aliyu, S. U. (2011). Oil price shocks and the macroeconomy of Nigeria: A non-linear approach. Journal for International Business and Entrepreneurship Development, 5(3): 179-198.

Asteriou, D., Masatci, K., \& PIlbeam, K. (2016). Exchange rate volatility and international trade: International evidence from the MINT countries. Economic Modelling, 58 (3):133-140. http://dx.doi.org/10.1016/j.econmod.2016.05.006

Avdjiev, S., Bruno, V., Koch, C., \& Shin, H. S. (2019). The dollar exchange rate as a global risk factor: evidence from investment. IMF Economic Review, 67(1): 151-173. http://dx.doi.org/10.1057/s41308-019-00074-4

Azeez, B. A., Kolapo, F. T., \& Ajayi, L. B. (2012). Effect of exchange rate volatility on macroeconomic performance in Nigeria. Interdisciplinary Journal of Contemporary Research in Business, 4(1): 149-155.

Babajide, A., Isola, L., \& Somoye, R. O. (2016). Stock market response to economic growth and interest rate volatility: Evidence from Nigeria. International Journal of Economics and Financial Issues, 6(1): 354-360.

Bagheri, M., \& Gheisarinejad, H. (2016). The impact of exchange rate fluctuations and inflation on the of deposit of customers (Case Study: Bank Saderat, Hormozgan Province). IIOAB Journal, 1(7): 270-276.

Bakhshi, Z., \& Ebrahimi, M. (2016). The effect of real exchange rate on unemployment. Marketing and Branding Research, 3 (1): 4-13. http://dx.doi.org/10.33844/mbr.2016.60281

Barguellil, A., Ben-Salha, O., \& Zmami, M. (2018). Exchange rate volatility and economic growth. Journal of Economic Integration, 33(2): 1302-1336. http://dx.doi.org/10.11130/jei.2018.33.2.1302.

Bristy, H. J. (2014). Impact of financial development on exchange rate volatility and long-run growth relationship of Bangladesh. International Journal of Economics and Financial Issues, 4(2): 258-263

Caselli, M., Chatterjee, A., \& Woodland, A. (2017). Multi-product exporters, variable markups and exchange rate fluctuations. Canadian Journal of Economics, 50(4): 1130-1160. http://dx.doi.org/10.1111/caje.12289.

Della Corte, P., Sarno, L., \& Tsiakas, I. (2009). An economic evaluation of empirical exchange rate models. The Review of Financial Studies, 22(9): 3491-3530

Eregha, P., Ndoricimpa, A., Olakojo, S., Nchake, M., Nyang'oro, O., \& Togba, E. (2016). Nigeria: should the government float or devalue the Naira?. African Development Review, 28(3): 247-263.

Eze, T. C., \& Okpala, C. S. (2014). Quantitative analysis of the impact of exchange rate policies on Nigeria's economic growth: A test of stability of parameter estimates. International Journal of Humanities and Social Science, 4(7): 265-272.

Fang, Y. (2020). Research on the impact of RMB exchange rate fluctuation on employment in my country. Academic Journal of Business \& Management, 2(6): 87-99. https://doi.org/10.25236/AJBM.2020.020612

Fauceglia, D. (2020). Exchange rate fluctuations and quality composition of exports: Evidence from Swiss product-level data. The World Economy, 43(6): 1592-1618. https://doi.org/10.1111/twec.12852.

Greenaway-McGrevy, R., Mark, N. C., Sul, D., \& Wu, J. L. (2018). Identifying exchange rate common factors. International Economic Review, 59(4): 2193-2218. https://doi.org/10.1111/iere.12334

Godfrey, O. U., \& Agwu, E. C. (2019). Exchange rate management and regime: Quo vadis Nigeria? International Journal of Economics and Financial Research, 5(12): 282-291.

Habib, M. M., Mileva, E., \& Stracca, L. (2017). The real exchange rate and economic growth: Revisiting the case using external instruments. Journal of International Money and Finance, 73(6): 386-398. https://doi.org/10.1016/j.jimonfin.2017.02.014

Isibor, A. A., Olokoyo, F. O., Arogundade, M., Osuma, G., \& Ndigwe, C. (2018). Exchange rate management and sectoral output performance. International Journal of Supply Chain Management, 7(5): 129-134.

Isola, L. A., Oluwafunke, A. I., Victor, A., \& Asaleye, A. (2016). Exchange rate fluctuation and the Nigeria economic growth. Euro Economica, 35(2):127-142.

Ismailov, A., \& Rossi, B. (2018). Uncertainty and deviations from uncovered interest rate parity. Journal of International Money and Finance, 88(5): 242-259. https://doi.org/10.1016/j.jimonfin.2017.07.012

Jadoon, A., \& Guang, Y. (2019). The effect of exchange rate fluctuations on trade balance of Pakistan. International Journal of Economic Sciences, 8(1): 68-80. https://doi.org/10.20472/ES.2019.8.1.005

Kaltenbrunner, A., \& Painceira, J. P. (2017). The impossible trinity: Inflation targeting, exchange rate management and open capital accounts in emerging economies. Development and Change, 48(3): 452-480. https://doi.org/10.1111/dech.12304

Kelikume, I., \& Nwani, S. E. (2019). A vector autoregression analysis of the efficacy of external reserves management on exchange rate stability: Evidence from Nigeria. Journal of Economics, Management and Trade, 24(5): 1-11. https://doi.org/10.9734/jemt/2019/v24i530173

Libman, E. (2018). The effects of exchange rate regimes on real exchange rate misalignment. International Review of Applied Economics, 32(1): 39-61. https://doi.org/10.1080/02692171.2017.1331205

Mostafapour, Y., Tehranchian, A. M., Jafari Samimi, A., \& Rasekhi, S. (2020). The study of threshold effects of exchange rate fluctuations on private investment in Iran. Quarterly Journal of Applied Theories of Economics, 7(1): 91-116.

Mundell, R. A. (1961). A theory of optimum currency areas. The American Economic Review, 51(4): 657-665.

McKinnon, R. I. (1963). Optimum currency areas. The American Economic Review, 53(4): 717-725. 


\section{International Journal of Management, Economics and Social Sciences}

Omoregie, O. K. (2020). Foreign exchange and the capital market dynamics: New evidence from non-linear autoregressive distributed lag model. International Journal of Management, Economics and Social Sciences, 9(1): 1-23.

Osabuohien, E. S. C., Obiekwe, E., Urhie, E. S., \& Osabohien, R. (2018). Inflation rate, exchange rate volatility and exchange rate pass-through nexus: The Nigerian experience. Journal of Applied Economic Sciences, 2(56): 574-585.

Oseni, I. O. (2016). Exchange rate volatility and private consumption in Sub-Saharan African countries: A system-GMM dynamic panel analysis. Future Business Journal, 2(2): 103-115. http://dx.doi.org/10.1016/j.fbj.2016.05.004

Pesaran, M. H., Shin, Y., \& Smith, R. J. (2001). Bounds testing approaches to the analysis of level relationships. Journal of applied econometrics, 16(3): 289-326.

Rashid, A., \& Waqar, S. M. (2017). Exchange rate fluctuations, firm size, and export behavior: An empirical investigation. Small Business Economics, 49(3): 609-625. https://doi.org/10.1007/s11187-017-9849-7

Rapetti, M., Skott, P., \& Razmi, A. (2012). The real exchange rate and economic growth: are developing countries different? International Review of Applied Economics, 26(6): 735-753. https://doi.org/10.1080/02692171.2012.686483

Salvatore, D. (2012). Exchange rate misalignments and the present international monetary system. Journal of Policy Modeling, 34(4): 594-604.

Senadza, B., \& Diaba, D. D. (2017). Effect of exchange rate volatility on trade in Sub-Saharan Africa. Journal of African Trade, 4(1-2): 20-36. http://dx.doi.org/10.1016/j.joat.2017.12.002

Usman, O., \& Elsalih, O. M. (2018). Testing the effects of real exchange rate pass-through to unemployment in Brazil. Economies, 6(3): 49-68 https://doi.org/10.3390/economies6030049

Vasani, S. A., Selvam, M., \& Selvam, M. (2019). Relationship between real exchange rate and economic growth in India. ZENITH International Journal of Business Economics and Management Research, 9(3): 19-35.

Vieira, F. V., \& MacDonald, R. (2016). Exchange rate volatility and exports: a panel data analysis. Journal of Economic Studies. 43 (2): 203-221 https://doi.org/10.1108/JES-05-2014-0083.

Vo, D. H., \& Zhang, Z. (2019). Exchange rate volatility and disaggregated manufacturing exports: Evidence from an emerging country. Journal of Risk and Financial Management, 12(1): 12-25 https://doi.org/10.3390/jrfm12010012.

Zakari, M. (2017). The impact of exchange rate fluctuations on foreign direct investment in Nigeria. Journal of Finance and Accounting, 5(4): 165-170. https://doi.org/10.11648/j.jfa.20170504.17 


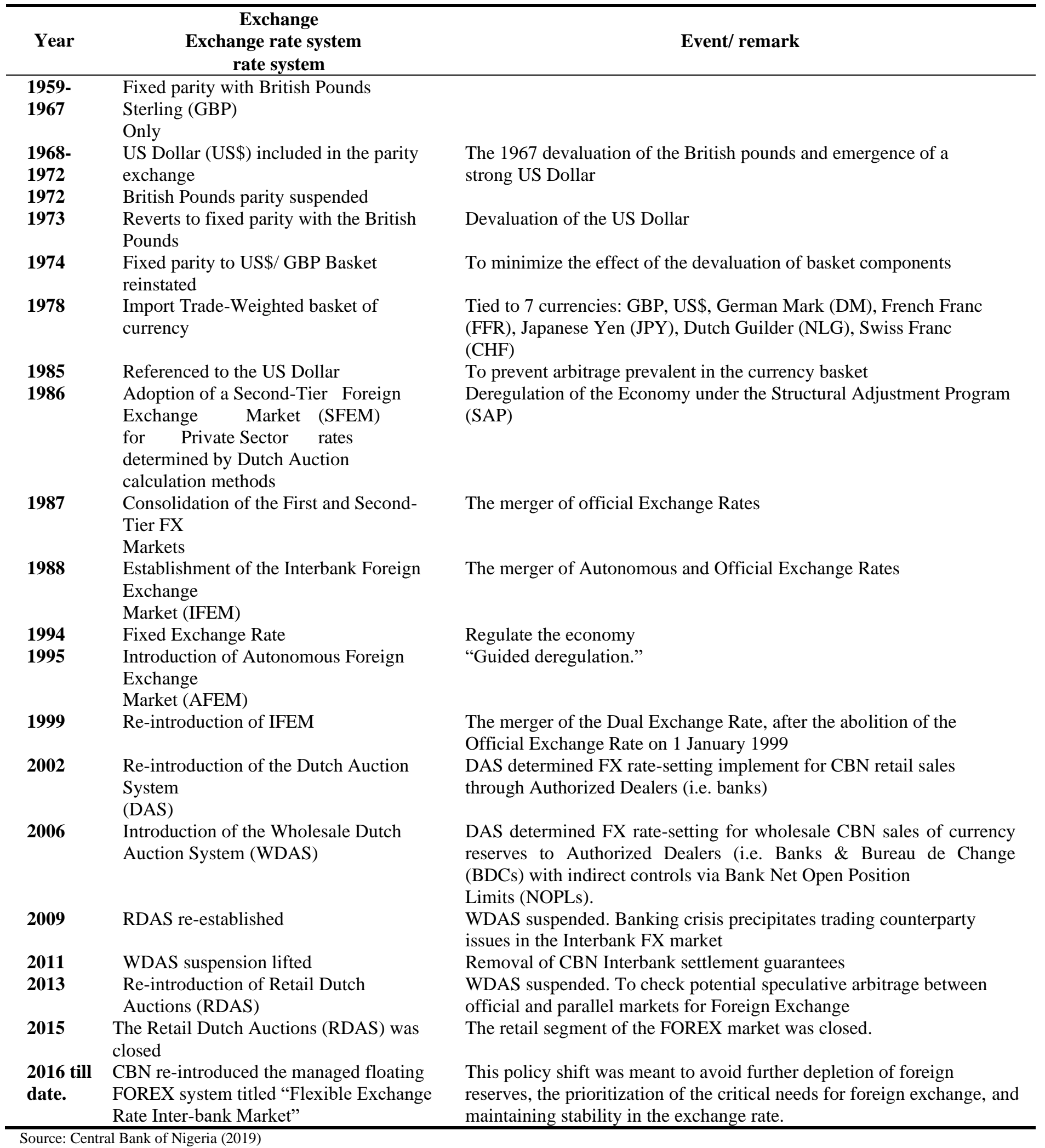

Table 1. Exchange Rate Regimes in Nigeria 


\begin{tabular}{cccc}
\hline \multicolumn{4}{c}{ Heteroskedasticity Test: Breusch-Pagan-Godfrey } \\
\hline$f$-statistic & 0.999309 & Prob. $f(14,16)$ & 0.4959 \\
Obs*R-squared & 14.46134 & Prob. Chi-Square(14) & 0.4159 \\
\hline
\end{tabular}

Source: Authors' Computation using EViews

Table 3. Result of Heteroscedasticity Test

\begin{tabular}{ccc}
\hline \multicolumn{3}{c}{ Breusch-Godfrey Serial Correlation LM Test } \\
\hline 0.669433 & Prob. $f(10,7)$ & 0.7275 \\
15.15402 & Prob. Chi-Square(10) & 0.1265 \\
\hline \multicolumn{2}{l}{ Source: Authors' Computation using EViews }
\end{tabular}

Table 4. Result of Autocorrelation test 
ARDL Error Correction Regression

Dependent Variable: D(GGDP)

\begin{tabular}{|c|c|c|c|c|}
\hline \multicolumn{5}{|c|}{ ECM Regression } \\
\hline Variable & Coefficient & Std. Error & $t$-Statistic & Prob. \\
\hline $\mathrm{D}(\mathrm{GGDP}(-1))$ & 0.347122 & 0.160355 & 2.164714 & 0.0449 \\
\hline $\mathrm{D}(\mathrm{GGDP}(-2))$ & 0.299250 & 0.109423 & 2.734796 & 0.0141 \\
\hline DLOG(EXR) & -5.549448 & 1.303626 & -4.256934 & 0.0005 \\
\hline $\mathrm{D}(\mathrm{NFDI})$ & -0.086207 & 0.293836 & -0.293384 & 0.7728 \\
\hline $\mathrm{D}(\mathrm{INF})$ & -0.228580 & 0.043542 & -5.249652 & 0.0001 \\
\hline $\mathrm{D}(\mathrm{INF}(-1))$ & 0.209759 & 0.034136 & 6.144754 & 0.0000 \\
\hline $\mathrm{D}(\mathrm{INF}(-2))$ & 0.046250 & 0.030064 & 1.538363 & 0.1424 \\
\hline $\mathrm{D}(\mathrm{INT})$ & 0.416456 & 0.131779 & 3.160254 & 0.0057 \\
\hline D(INT(-1)) & -0.756670 & 0.188335 & -4.017689 & 0.0009 \\
\hline $\operatorname{CointEq}(-1)^{*}$ & -0.928173 & 0.172720 & -5.373858 & 0.0001 \\
\hline
\end{tabular}

Source: Authors' Computation using EViews

Table 7. Estimated ARDL Short Run Coefficients 


\begin{tabular}{ccccc}
\hline Variable & Coefficient & Std. Error & $\boldsymbol{t}$-Statistic & Prob. \\
\hline LOG(EXR) & -1.630324 & 0.592846 & -2.749994 & 0.0137 \\
NFDI & -0.589014 & 0.261613 & -2.251468 & 0.0379 \\
INF & -0.307370 & 0.078349 & -3.923105 & 0.0011 \\
INT & 0.879768 & 0.196250 & 4.482889 & 0.0003 \\
\hline
\end{tabular}

Source: Authors' Computation using EViews

Table 8. Estimated ARDL Long Run Coefficients 